\title{
Factor Related to Urine Trans, Trans-muconic Acid (TT-MA) Levels of Shoemaker in Tambak Oso Wilangun Surabaya
}

\author{
Sam Sam Eka Bada ${ }^{1}$, Abdul Rohim Tualeka ${ }^{1}$, Noeroel Wida jati ${ }^{1}$ \\ ${ }^{1}$ De partement of Occupational Health and Safety, Airlangga University, Surabaya Indonesia
}

\begin{abstract}
Benzene is one of the components contained in the glue which is used in shoe-making process of home industry activities. The using of Benzene in a long period can cause hematologic disorders. The exposure of benzene in the working environment of the shoemaker is related to the individual characteristics and the conditions of the working environment. The level of trans, trans muconic acid (tt-MA) in the urine is a manifestation of a research subject's exposure to benzene exposure in the workplace.
\end{abstract}

The purpose of this study was to analyze factors related to urine tt-MA levels of shoemaker. This study was an observational research, and the design of study is a cross-sectional research with 20 people as the research subjects. The independent variables were age, gender, nutritional status, working hours (hour/ day), working periods (year) and smoking habit, whereas the dependent variable was urine tt-MA levels.

The mean of benzene level in the air is $0.5111 \mathrm{ppm}$ and the mean of urine tt-MA levels is $555,65 \mu \mathrm{g} / \mathrm{g}$ creatinine. Pearson correlation test indicated that there is a significant relationship between the working hours (hour/ day) with the urine tt-MA levels of the research subjects $(\mathrm{p}=0.040)$.

Continuous counseling needs to be carried out considering the risks of chemical substances in the home industry of shoes. In addition, the application of the regulation of 5R principles in the workplace is necessary, and maintaining personal hygiene and expanding ventilation as well as providing plantation to reduce the benzene vapor in the working environment of the shoemaker is important.

Keywords : Glue, Benzene, Shoemaker, Urine trans, trans-muconic acid (tt-ma) levels

\section{INTRODUCTION}

One of inf ormal sector which gives a strong influence in the development of Indonesia is the home industry of footwear with a total value of $\$ 1.51$ millions. The characteristics of footwear informal industry is that this industry is very vulnerable to the hazards of chemical elements ${ }^{1 .}$ Generally, glues or adhesives contain various combination of chemical elements including benzene which has function as a solvent.

Benzene is a hazardous chemical element and it is carcinogenic to human ${ }^{2}$. The most significant toxic effects upon exposure to benzene is bone marrow damage ${ }^{3 .}$ Related research of biochemical and hematological analysis on the shoemaker in Pakistan found that there is a significant result of changes in the levels of blood profile of the shoemaker workers compared to the control group 4 .
Benzene that enters the body will undergo metabolism into benzene epoxide. Benzene epoxide is an unstable compound and it will undergo oxidation to form trans, trans-muconaldehyde then turn into trans, trans Muconic Acid which is excreted in the urine. One of sensitive and relevant indicators to measure the exposure and dosage of benzene entering the body is by using a biomarker which is trans, trans Muconic Acid (t, t-MA) contained in the urine ${ }^{5}$. The level of tt-MA in the urine will be able to detect the exposure of benzene at concentrations of up to $0.1 \mathrm{ppm}^{6}$.

The amount of benzene entering the body of the shoemaker can not be separated from the related characteristics of the individual and their working environment. Age affects the body resistance to toxic exposure, the older the worker, the higher the risk of benzene poisoning?. Gender also related with the 
susceptibility of benzene toxicity which is lipophilic in which women have more body fat than men ${ }^{8}$. Working hours (hours/ day), working periods (year) is closely related to the large exposure to the hazardous substances and the onset of disease if it exceeds within the specified limits. Nutritional status is also an important factor in the process of health risk analysis, if the nutritional status of workers are within the normal level, the process of blood cell formation will goes normal ${ }^{10}$. Smoking habits will increase the amount of benzene intake, benzene in cigarette smoke is around 25.5 to $63.7 \mathrm{~g} /$ stick of cigarette ${ }^{11}$

Indonesia sets a Threshold Limit Value (TLV) for benzene of $0.5 \mathrm{ppm}$ which is according to the regulation ${ }^{12}$. The Biological Exposure Indices at work on the exposure of benzene fro the biomarker of tt-MA biomarkers in urine is at $500 \mathrm{ug} / \mathrm{g}$ creatinine ${ }^{6}$.

The results of observations on the shoemaker in the home industry of Tambak Oso Wilangun Surabaya indicated some characteristics, such as unhealthy working environment, bad ventilation, no PPE (mask), the glue container used is always open, the workers also do not wear clothes and smoking at work. The workers seem to have complaints such as dizziness, shortness of breath and stinging in the eyes, which indicates that their bodies have been expose to benzene.

The purpose of this study was to analyze the relationship of the research subjects characteristics including age, sex, nutritional status, working hour (hours/ day), working period (years) and smoking habits with the levels of urine tt-MA.

\section{MATERIAL AND METHOD}

This study applied a cross sectional design with an obeservational type, obtained 20 people as the subjects selected based on certain criteria. The research was conducted in 7 home industries of footwear in Tambak Oso Wilangun Surabaya, held in November 2016. To determine the level of benzene exposure in the body of the shoemaker was done measurement of biomarker of urine tt-MA, and to determine the levels of benzene in the working environment was done benzene measurements in the air.

This study applied some research instruments such as questionnaire, observation sheets and interview notes. All the subjects was given instruction and completed the informed consent prior to the measurement.

\section{FINDINGS}

The characteristics of subjects in this study can be seen in the following table 1 :

Tabel 1. Subject characteristics

\begin{tabular}{|c|c|c|c|c|}
\hline \multirow{2}{*}{ No } & \multirow{2}{*}{ Variable } & \multirow{2}{*}{ Category } & \multicolumn{2}{|c|}{ Result } \\
\hline & & & $\mathbf{n}$ & $\%$ \\
\hline \multirow{3}{*}{1} & \multirow{3}{*}{$\begin{array}{l}\text { Age } \\
\text { (years) }\end{array}$} & $\min (23)$ & - & - \\
\hline & & $\max (62)$ & - & - \\
\hline & & mean $(46,05)$ & - & - \\
\hline \multirow{2}{*}{2} & \multirow{2}{*}{ Sex } & male & 10 & 50 \\
\hline & & female & 10 & 50 \\
\hline \multirow{3}{*}{3} & \multirow{3}{*}{$\begin{array}{l}\text { Nutritional } \\
\text { Status (BMI) }\end{array}$} & thin $(<18.5)$ & 1 & 5 \\
\hline & & normal(18.5-22.9) & 4 & 20 \\
\hline & & $\operatorname{fat}(>22.9)$ & 15 & 75 \\
\hline \multirow{3}{*}{4} & \multirow{3}{*}{$\begin{array}{l}\text { Working } \\
\text { Hours } \\
\text { (hours/day) }\end{array}$} & $\min (6)$ & - & - \\
\hline & & $\max (15)$ & - & - \\
\hline & & mean $(11,08)$ & - & - \\
\hline \multirow{3}{*}{5} & \multirow{3}{*}{$\begin{array}{l}\text { Working } \\
\text { Periods } \\
\text { (years) }\end{array}$} & $\min (2,5)$ & - & - \\
\hline & & $\max (43)$ & - & - \\
\hline & & mean $(25,7)$ & - & - \\
\hline \multirow{2}{*}{6} & \multirow{2}{*}{$\begin{array}{l}\text { Smoking } \\
\text { habit }\end{array}$} & Smoker & 7 & 35 \\
\hline & & Not smoker & 13 & 65 \\
\hline
\end{tabular}

Information : *BMI (Body Mass Index) is the ratio of weight $(\mathrm{kg})$ by the square of height (meters).

In collecting the data of the characteristics of the subjects was done by interviewing the respondents by using a questionnaire which consists of age, sex, working hours and working periods and smoking habit. Whereas to collect the data of nutritional status was done by using the indicator measurements of Body Mass Index (BMI), the data of height and weight.

The measurement of environment was conducted to determine the level of benzene exposed in the working environment. The results of measurements of the level of benzene in the air can be seen in the following table 2: 
Table 2. The Level of Benzene in the Air

\begin{tabular}{|l|l|l|}
\hline \multirow{2}{*}{$\begin{array}{l}\text { Work } \\
\text { Location }\end{array}$} & $\begin{array}{l}\text { Point } \\
\text { (Floor })\end{array}$ & $\begin{array}{l}\text { Level of Benzene } \\
(\mathbf{p p m})\end{array}$ \\
\hline Location A & 1 & 0,3975 \\
\hline Location B & 2 & 0,0129 \\
\hline Location C & 3 & 0,3503 \\
\hline Location D & 4 & 0,0193 \\
\hline Location E & $5\left(1^{\text {st floor })}\right.$ & $0,9129^{*}$ \\
\hline Location F & $6\left(2^{\text {nd }}\right.$ floor $)$ & $2,3330^{*}$ \\
\cline { 2 - 3 } & 7 & 0,0182 \\
\hline Location G & 8 & 0,0485 \\
\hline mean & & 0,5111 \\
\hline max & & 2,3330 \\
\hline $\min$ & & 0,0129 \\
\hline
\end{tabular}

* Exceeding TVL levels ${ }^{12}$

The mean of benzene level in the air of home industry working environment is $0.5111 \mathrm{ppm}$ with the highest levels at 2.3330 and the lowest level at 0.0129 ppm ppm.

The chemicals occur in their working environment, which is particularly derived from the glue may effects the physical health such as blood level abnormality. The different levels of benzene occur in each working location is caused by several things, they are: the number of shoes produced in the production, the type of raw materials used for the shoes, the technique/methods of work, and the lack of sufficient ventilation.

In addition, a biomarker measurement of urine ttMA levels to determine the level of benzene exposed in the body on the benzene exposed in the working environment. The result of measurement of tt-MA level in the research subjects can be seen in the following table 3:

Tabel 3. The level of tt-MA in the Subjects

\begin{tabular}{|l|l|l|l|}
\hline $\begin{array}{l}\text { Work } \\
\text { Location }\end{array}$ & Point & Shoemaker & $\begin{array}{l}\text { Level of tt-MA } \\
(\boldsymbol{\mu g} / \mathrm{g} \text { creatinine })\end{array}$ \\
\hline \multirow{4}{*}{$\begin{array}{l}\text { Location } \\
\mathrm{A}\end{array}$} & \multirow{2}{*}{1} & $a$ & 466,71 \\
\cline { 3 - 4 } & & $b$ & 244,86 \\
\hline & & $c$ & 247,93 \\
\hline \multirow{2}{*}{$\begin{array}{l}\text { Location } \\
\mathrm{B}\end{array}$} & \multirow{2}{*}{2} & $e$ & 421,66 \\
\hline & & $f$ & 152,53 \\
\hline & & $g$ & 327,50 \\
\hline
\end{tabular}

Cont... Tabel 3. The level of tt-MA in the Subjects

\begin{tabular}{|c|c|c|c|}
\hline \multirow{3}{*}{$\begin{array}{l}\text { Location } \\
\mathrm{C}\end{array}$} & \multirow{3}{*}{3} & $h$ & 417,17 \\
\hline & & $i$ & $577,48^{*}$ \\
\hline & & $j$ & 250,63 \\
\hline \multirow{2}{*}{$\begin{array}{l}\text { Location } \\
\text { D }\end{array}$} & \multirow{2}{*}{4} & $k$ & $960,29 *$ \\
\hline & & $l$ & $874,07 *$ \\
\hline \multirow{3}{*}{$\begin{array}{l}\text { Location } \\
\text { E }\end{array}$} & $\begin{array}{l}5\left(1^{s t}\right. \\
\text { floor })\end{array}$ & $m$ & 388,42 \\
\hline & \multirow{2}{*}{$\begin{array}{l}6\left(2^{\text {nd }}\right. \\
\text { floor })\end{array}$} & $n$ & $1.731,38^{*}$ \\
\hline & & $o$ & $775,08^{*}$ \\
\hline \multirow{3}{*}{$\begin{array}{l}\text { Location } \\
\text { F }\end{array}$} & \multirow{3}{*}{7} & $p$ & $1.363,66^{*}$ \\
\hline & & $q$ & $552,49 *$ \\
\hline & & $r$ & 286,86 \\
\hline \multirow{2}{*}{$\begin{array}{l}\text { Location } \\
\text { E }\end{array}$} & \multirow{2}{*}{8} & $s$ & 57,59 \\
\hline & & $t$ & 296,12 \\
\hline \multicolumn{3}{|l|}{ mean } & 555,65 \\
\hline \multicolumn{3}{|l|}{$\max$} & $1.731,38$ \\
\hline \multicolumn{3}{|l|}{$\min$} & 57,59 \\
\hline
\end{tabular}

The urine test was done at the end of the working shift since it is a gold period of the peak accumulation of metabolites tt-MA ${ }^{5 .}$ The mean of urine tt-MA levels is $555,65 \mu \mathrm{g} / \mathrm{g}$ creatinine, there are eight respondents who had higher levels of tt-MA exceed the limit of BEI.

Statistical test analysis was done to determine the relationship of subject characteristics with the levels of urine tt-MA. To determine the relationship, variables with data ratio scale was analyze by using Pearson Correlation test. Whereas, variables with ordinal data scale was analyze by using Spearman correlation test. Besides, the nominal variable (sex) was analyzed by using t-test to find out the difference of tt-MA levels between male and female. The results of the test on the relationship of those variables can be seen in the following table 4 .

\section{Tabel 4. The Test Result of The Relationship}

of the Subjects Characteristics with the Urine tt-MA Levels

\begin{tabular}{|l|l|l|l|}
\hline No & Variables & p-value & Result \\
\hline 1 & Age & 0,965 & Insignificant \\
\hline 2 & Sex & 0,896 & Insignificant \\
\hline 3 & Nutritional status (BMI) & 0,492 & Insignificant \\
\hline 4 & Working Hours (hours/day) & 0,040 & Significant \\
\hline 5 & Working Periods (years) & 0,927 & Insignificant \\
\hline 6 & Smoking habit & 0,064 & Insignificant \\
\hline$(\alpha=0,05)$ & \multicolumn{2}{|l}{} \\
\hline
\end{tabular}


Table 4 shows that there is a significant relationship between the variable of working hours (hours/day) with the level of urine tt-MA in the subject with a value of $p$ $=<0.05$.

\section{Age}

The high levels of urine tt-MA of individuals is considered as the tendency of the factor of age that affects the decreased function of the body's metabolism $(>45 \text { years old })^{13}$. However, the result of this study indicated that high levels of tt-MA also found in the subjects at the age of $<45$ years old. In accordance with the research by Fakhrinnur et al, (2016) ${ }^{14}$, also concluded that the variable of age is not dominant in relation to the levels of tt-MA since respondents at the age of $<45$ years also consider to have high levels of $\mathrm{tt}-\mathrm{MA}$, therefore, the variable of age has no relationship with the levels of urine tt-MA in the respondents.

\section{Sex}

There is no difference in the levels of urine tt-MA between male and female. The results of the level of urine tt-MA of the subjects determined by gender are relatively similar. Liver has function as the metabolism of benzene and tt -MA in the subjects which is not discover in this study. Therefore, this is considered as the limitation in this study, since the liver function will affect the metabolism of a chemical substance ${ }^{2}$.

\section{Nutritional Status}

Based on the results of body mass index measurements, obtained the mean of BMI is 27.13 or overall subject categorized as fat. This study does not similar with the research conducted by Waritz $(1995)^{15}$ who states that obesity may decrease the elimination rate of lipophilic subtance (benzene) in the liver. The result of this study indicated no relationship between the two variables since the nutritional status of the subjects cannot represent the overall nutritional history during the previous period, whereas benzene poisoning occurs chronically and accumulative, which then influenced by the nutritional history of the individuals ${ }^{14 .}$

\section{Working Hours (hour/hari)}

The result of this study indicated that working hours has a significant relationship with the level of urine tt-MA. To extend the working hours per day can increase the exposure to the chemical subtances in the working place ${ }^{9}$. The results of this study is supported by the research conducted by Mansour et al, $(2012)^{16}$ conducted in the footwear industry in East Tehran, adding the working hours will directly proportional with the amount of chemicals subtance (glue) usage in the production process result in the increase of severity of benzene exposed in the body. The duration of workers exposed to the chemical subtances in a matter of hours per day has a relationship with the levels of benzene in the urine of the workers themselves ${ }^{17 .}$

\section{Working Period (year)}

Working period does not have a relationship with the levels of urine tt-MA. Working period of more than 30 years is considered as the period effect of noncarcinogenic toxicant subtances which can be manifested in the human ${ }^{18 .}$ However, it was found in the research subject that the level of tt-MA is higher than the level of BEI with the tenure of $>30$ years, meanwhile, the working hours per day is more than 8 hours. This means that the working hours per day has a more significant relationship with the level of tt-MA compared to tenure. This also indicated that the excretion of tt-MA in the urine is at culmination after 4-5 hours exposure, therefore, the urine sample should be collected soon after the exposure happen ${ }^{5}$

\section{Smoking Habit}

In this study, smoking does not have a relationship with the level of urine tt-MA. The results of this study is in accordance with the research conducted by Martin et al, (2004) $)^{19}$ concerning the level of urine tt-MA of worker with high exposure of benzene, there is no significant difference between workers who have smoking habit and those who do not have smoking habit.

This study recommends that the should government undertake continuous health education, and for the shoes craftsmen shoes to optimize ventilation and maintain personal hygiene. For the next researcher to use personal sampler tools to determine the level of exposure of each individual received.

\section{CONCLUSION}

1. The mean of benzene levels in the air of the home industry working environment is at $0.5111 \mathrm{ppm}$, exceeding the Threshold Limit Value (TLV). 
2. The mean of trans, trans muconic acid (tt-MA) levels in the urine of the subject is at $555.65 \mu \mathrm{g} / \mathrm{g}$ creatinine, exceeding the Biological Exposure Indices (BEI).

3. There is a relationship between the working hours (hours/ day) with the levels of urinett-MA of the subject.

\section{Conflict of Interest: None}

Source of Funding: Departement of Occupational Health and Safety, Airlangga University, Surabaya Indonesia

Ethical Clearance: The study was approved by the institutional Ethical Board of the Public Health, Airlangga University.

All subjects were fully informed about the procedures and objectives of this study and each subject prior to the study signed an informed consent form.

\section{REFERENCES}

1. ILO. Pekerja Anak di Industry Sepatu Informal di Jawa Barat Sebuah Kajian Cepat. Jakarta: Copyright International Labour Organization. 2004.

2. ATSDR. Toxicological Profiles for Benzene. US Department of Health and Human Service, Public Health Service, Atlanta, Georgia: Agency for Toxic Substance and Disease Registry. 2007

3. Jeffrey, S.K., Brent, D.K., Dennis, J.P.. A Clibrated Human PBPK Model for Benzene Inhalation with Urinary Bladder and Bone Marrow Compartments. Risk Analysis. 2013: 33(7):1237-1251.

4. Khan, Ayaz Ali., Sultan Reshma., Zamani G. Y. Biochemical and Hematological Analysis after Exposure to Hazardous Materials during Shoe Making. University of Malakand Chakdara, Dir (Lower), Khyber Pakhtunkhwa, Pakistan. Journal of Biology and Life Science. ISSN 2013: 21576076 Vol. 4, No. 2.

5. WHO. Biological Monitoring of Chemical Exposure in The Workplace. Geneva: World Health Organization. 1996.

6. ACGIH. Threshold Limit Value for Chemical Substances and Physical Agents and Biological Exposure Indices. Cincinnati: American
Conferrence Governmental Industrial Hygienists. 2015.

7. Mahawati. Hubungan Antara Kadar Fenol Urin Dengan Kadar Hb, Eritrosit, Trombsit, Dan Leukosit (Studi Pada Tenaga Kerja di Industri Karoseri CV Laksana Semarang. Jurnal Kesehatan Lingkungan Indonesia: Vol. 5 No.1, April. 2006.

8. Sato. Kinetic Studies on Sex Difference Insusceptibility to Chronic Benzene Intoxicationwith Special Reference to Body Fat Content. Japan:mShinshu University Faculty of Medicine. 1975.

9. Suma'mur. Higiene Perusahaan dan Kesehatan Kerja (Hiperkes). Jakarta: Seagung Seto. 2009.

10. Hoffbrand, A.V., Pettit, J.E., Moss, P.A.H. Kapita Selekta Hematologi. Cetakan Pertama. Jakarta: Penerbit EGC. 2005.

11. Mitacek, E.J., Brunnemann, K.D., Polednak, A., Limsila, Bothisuwan, K., Hummel, C.F. Rising Leukemia Rates In Thailand : The Possible Arnita Role Of Benzene And Related Compounds In Cigarette Smoke. PubMed: 9(6):1339-403. 2002.

12. Republik Indonesia, Permenakertrans PER.13/ MEN/X/2011 tahun 2011 tentang NAB Faktor Fisika dan Kimia di Tempat Kerja. Jakarta.

13. Budiono, Sugeng. Bunga Rampai Hiperkes dan Kesehatan Kerja, Semarang: Badan Penerbit Undip. 2003.

14. Fakhrinnur., Martiana., Dewanti Linda,. Factor Associated with Urine tt-MA Levels of Gas Station Workers. (IJAEMS). Vol-2 Issue June 6. ISSN:2454-1311. 2016.

15. Waritz, Richard. Biological Markers of Chemical Exposure, Dosage, and Burden. Patty's Industrial Hygiene and Toxicology. 3rd edition, Volume III, Part B, Theory and Rationale of Industrial Hygiene. Practice : Biological Responses New York: John Wiley \& Sons, Inc.,: 79-137. 1995.

16. Mansour R., Hosseini., Javad Jafari., Soori Hamid., Asadi Parisa., Mousavion Mohammad. Evaluation of Occupational Exposure of Shoe Makers to Benzena and Toluene Compounds in Shoe Manufacturing Workhsop in East Tehran. Iran: National Research Institute of Tuberculosis and Lung Disease. ISSN: 1735-0344 Tanaffos 2012; 11(4):43-49.2012 
17. Yuniati, Ita. Hubungan Praktik Kerja, Pajanan Benzena dan Kebiasaan Merokok Dengan Konsentrasi Benzena Dalam Urin. Skripsi. Semarang: Universitas Muhammadiyah. 2016.

18. EPA. Toxicological Review of Benzena (NoncancerEffects).IARC MONOGRAPHS SUPPLEMENT. 2002.
19. Martins Isarita., de Siqueira Maria Elisa Pereira Bastos. TT-MA In Urine Samples Collected In Three Periods From Benzene Handling Workers In A Brazilian Refinery. Sao Paolo: Revista Brasileira de Ciências Farmacêuticas Brazilian Journal of Pharmaceutical Sciences. Vol. 40, n. 2, abr/jun., 2004 